\title{
Surgical Treatments for Legg-Calvé-Perthes Disease: Comprehensive Review
}

Arash Maleki, MD; Seyyed Mohammad Qoreishy, MD; Mohammad Nabi Bahrami, MD

Orthopedic Department, Shahid Beheshti University of Medical Sciences, Tehran, Iran

Corresponding Author:

Mohammad Nabi Bahrami, MD

Orthopedic Department

Shahid Beheshti University of Medical Sciences

Arabi Ave, Daneshjoo Blvd, Velenjak

Tehran

Iran

Phone: 989178851457

Email: mnabibahrami1364@gmail.com

\section{Abstract}

Background: Legg-Calvé-Perthes disease (LCPD) is a common public health problem that usually occurs between the ages of 4 and 8 years, but it can occur between the ages of 2 and 15 years. This condition occurs due to the interruption of blood supply to the femoral head. Up to now, different surgical and nonsurgical treatments, including femoral varus osteotomy, innominate osteotomy, pelvic osteotomies, triple osteotomy, Chiari osteotomy, and shelf acetabuloplasty, have been suggested for noncontainable LCPD hips.

Objective: The aim of this comprehensive review was to investigate the various surgical techniques used for LCPD.

Methods: An advanced electronic search of the English-language literature was performed from October 8 to 14, 2020. The electronic databases PubMed, MEDLINE, Web of Science, Embase, Ovid, and Google scholar were searched using appropriate search terms. A manual search of references also was performed. After retrieving the studies, duplicates were removed, and the remining studies were screened based on the title, abstract, and full text. The quality of the selected articles was assessed, and the required data were extracted from eligible articles.

Results: A total of 22 studies were included in the review. Based on the results of the reviewed studies, there are three main factors that influence the treatment outcomes in patients with Perthes disease. These factors are onset age, femoral head involvement severity, and treatment method. The disease has a poor prognosis in children over 8 years old, but this group of patients can also benefit from advanced surgical methods. In patients aged less than 6 years, the disease has a generally good prognosis, but in those aged between 6 and 8 years, its prognosis is variable. Thus, the need for surgical intervention requires close observation of signs. Once any head signs are observed, dynamic arthrography is beneficial before choosing the treatment approach.

Conclusions: This review provides clinicians with a brief guideline for the treatment of patients with LCPD.

(Interact J Med Res 2021;10(2):e27075) doi: 10.2196/27075

\section{KEYWORDS}

surgical treatment; Legg-Calvé-Perthes disease; pediatric; hip; treatment outcome

\section{Introduction}

Legg-Calvé-Perthes disease (LCPD) is a common childhood disease that commonly occurs between the ages of 4 and 8 years, but it can be found between the ages of 2 and 15 years. This condition occurs owing to the interruption of blood supply to the femoral head. The disease, which is described as aseptic necrosis of the juvenile femoral head, affects about 10 in 100,000 children worldwide [1-3]. Therefore, it is a common

condition of the hip in childhood that was first recognized in 1910 by three physicians working independently, including Thornton Legg, Jacques Calvé, and Georg Perthes [4,5]. LCPD is characterized by idiopathic osteonecrosis of the femoral epiphysis that is attributed to arterial infarction [6]. Waldenström has indicated that the process of disease progression commences with aseptic necrosis, followed by a subchondral fracture and fragmentation, revascularization, and remodeling $[7,8]$. The prevalence of the disease is higher in boys than in girls $[9,10]$. Additionally, it is more prevalent between the ages of 4 and 8 
years, and late onset of the disease in children above these ages has poorer results compared with onset at lower ages [11]. Current literature suggests that between $30 \%$ and $50 \%$ of children affected by LCPD will experience hip symptoms in adulthood [12,13]. Previous studies have documented some ethnic and geographical disparities in the incidence of LCPD [14].

The formation and progression of LCPD begins with the interruption of femoral head blood supply, which consequently results in changes in the femoral head, metaphysis, growth plate, and acetabulum (Figure 1). Subluxation and lateral displacement of the femoral head out of the acetabulum are among the first signs of the condition [15]. The femoral epiphysis is sensitive to deformation by loading. Lateral migration leads to deformation of the femoral head owing to presence on the edge of the acetabulum and uneven transfer of loading force [16]. Current LCPD treatment focuses on mechanical protection of the femoral head to prevent future hip deformity and degeneration [17], which maintains the plastic epiphysis in the acetabulum and can be done either by noninvasive or surgical techniques [18-20]. Clinicians use the concept of "at risk joint" as the conclusive criterion for the prognosis and treatment options of LCPD [21]. Additionally, imaging methods are used in patient assessment, which provide beneficial information and enable physicians to choose the best case-based strategy for disease management [22,23].

Figure 1. In the normal hip joint, the femoral head is smooth and round (left). In Perthes disease, the femoral head is damaged and loses its normal shape (right).

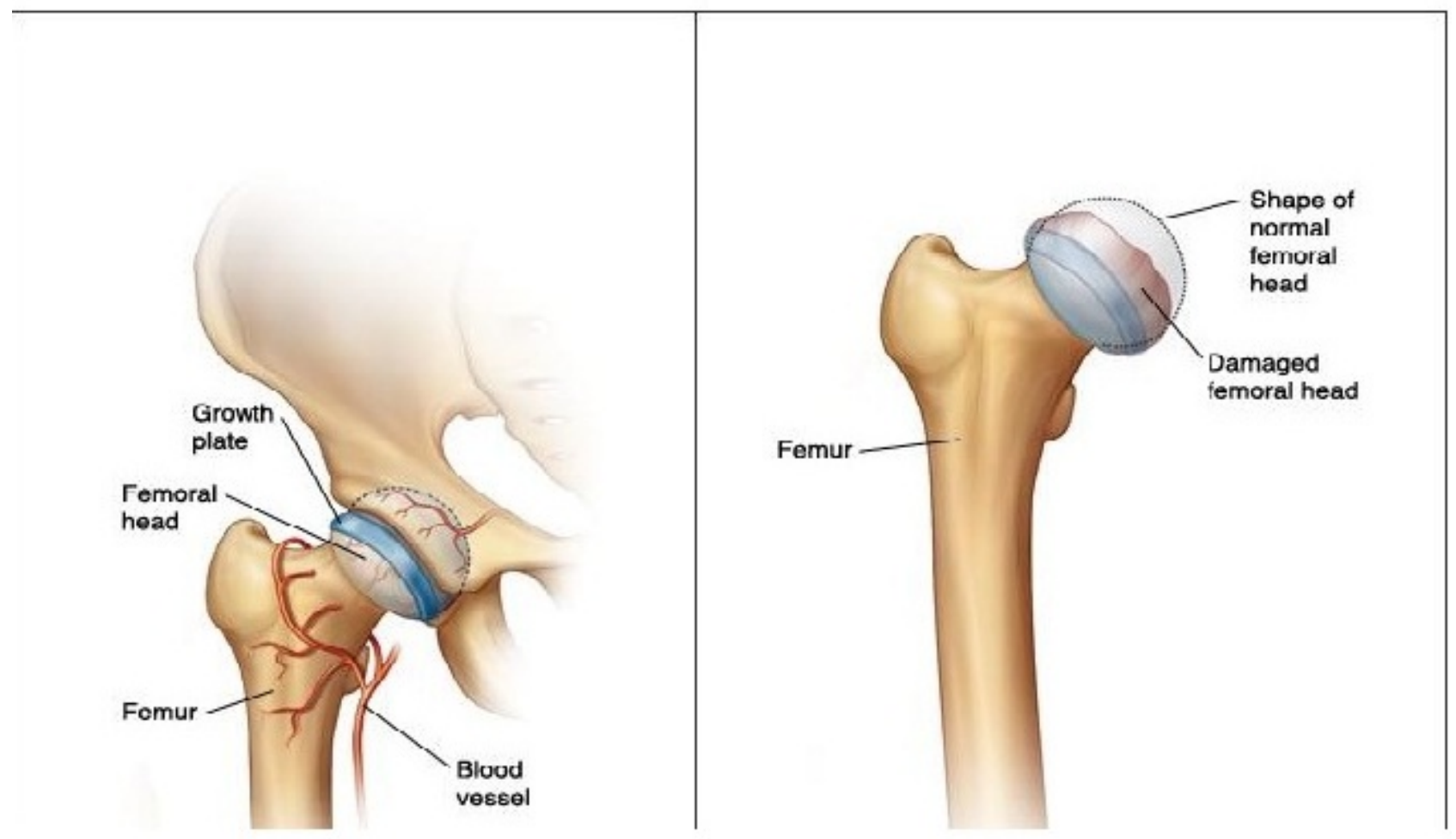

In general, LCPD, which is a childhood hip disorder and is related to interruption of blood supply, progresses over a rage of stages, including necrosis/initial, fragmentation, reossification/healing, and residual [7,24]. Follow-up studies indicate that up to $70 \%$ of patients will experience substantial hip pain and dysfunction caused by the disease until adulthood $[25,26]$. However, the majority of patients have a benign long-term prognosis and need minimal treatment [26]. Treatment of patients focuses primarily on maintaining the femoral head within the acetabulum during the remodeling period [27]. Many studies have been published regarding the treatment options for LCPD; however, the specific therapies are still controversial owing to a poor understanding of its etiology [28]. Treatment options vary from doing nothing to undergoing nonoperative or operative treatments, which have been reported to preserve containment. Nowadays, containment, which can be done with surgical and nonsurgical methods, is suggested as a means for directing the remodeling of the softened femoral head [29-31].

Current treatments for LCPD are largely focused on the early containment of the vulnerable femoral head in the acetabulum to keep the spherical femoral head and congruent joint during the repair period [32,33]. Nonoperative containment options, such as motion therapy, weight relief, and abduction splints, are more appropriate for younger patients, while surgical options are more suggested for older children with more severe LCPD [34]. In the past years, different surgical methods have been developed for treating LCPD, which were claimed to be more appropriate options than nonsurgical treatments for more severe cases of the disease and older patients $[1,35,36]$. Choosing the best treatment option for the management of LCPD depends on various factors, such as the physician's own preferences, the patient's age and disease stage, and the psychosocial status of 
the patient and family [37-42]. Since various surgical techniques have been proposed for the hips in noncontainable LCPD, the aim of this study was to review the various surgical treatments in LCPD to provide a guide for clinical applications. Some reviews have been published on LCPD management, but each of them has a specific focus. For example, some studies categorized the treatment options as conservative and surgical treatments, with a brief description of each, but in this article, we aimed to review the surgical treatments for LCPD in detail, which differentiates this review from other published studies.

\section{Methods}

\section{Databases and Search Strategy}

We conducted an overview of the English-language literature involving various surgical treatments for LCPD. The electronic databases PubMed, MEDLINE, Web of Science, Embase, and Ovid were searched from October 8 to 14, 2020, for reports on the outcomes of surgical techniques in patients with LCPD. The search was updated on February 4 to 6, 2021. All published studies from January 01, 2000, to the search date were assessed for possible inclusion in this study.

Reference lists of published papers were then hand searched in an attempt to identify further studies (Figure 2). The following keywords were used: Legg-Calvé-Perthes disease, pediatric orthopedic diseases, Perthes disease treatment, avascular necrosis of the hip, osteonecrosis of the femoral head, surgical treatment, osteotomy, hip, and treatment outcome. The search terms were then entered into Google Scholar to ensure that articles were not missed.

Figure 2. Literature search and review flowchart for the selection of primary studies.

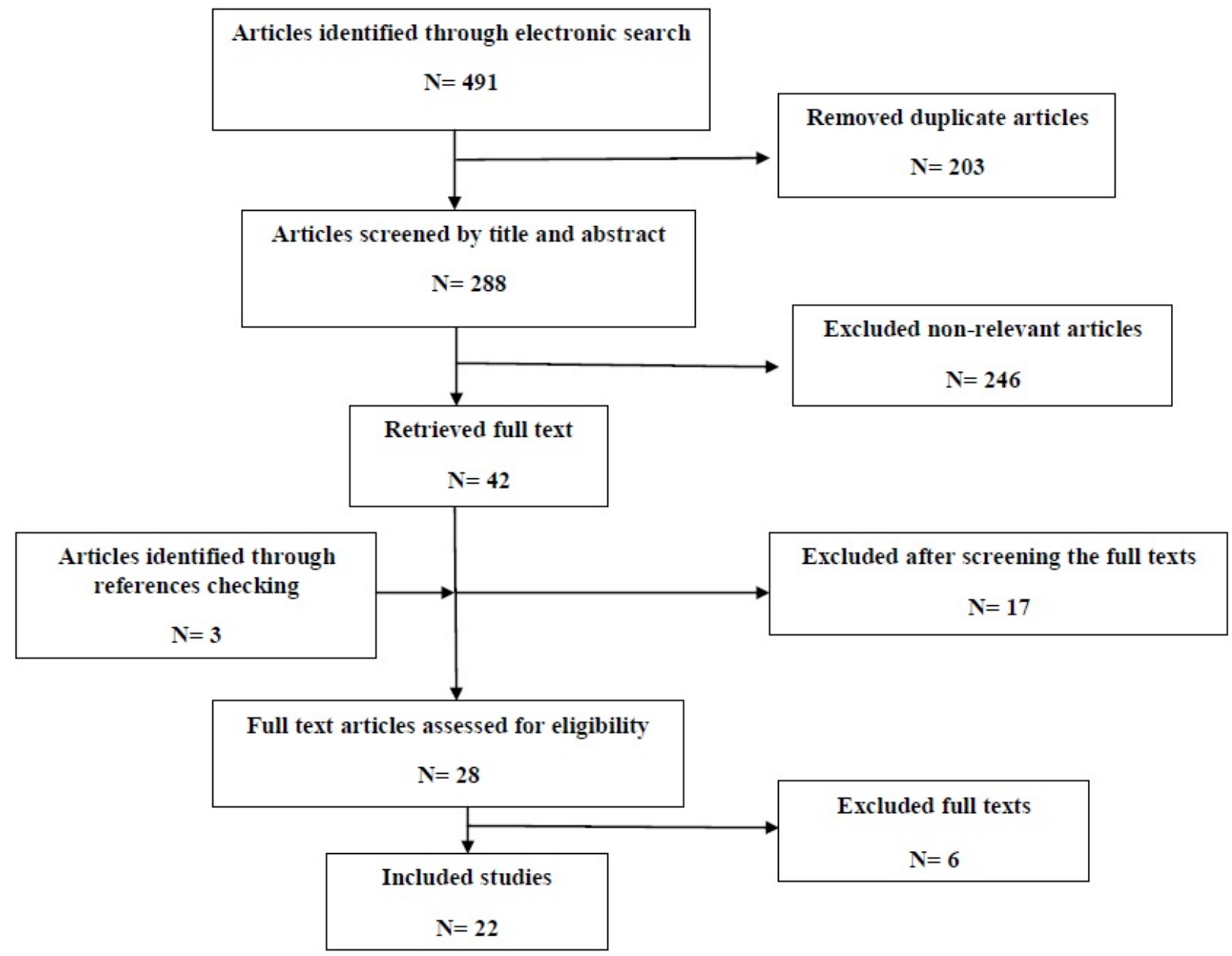

\section{Inclusion Criteria}

Studies written in English that reported various aspects of surgical treatments for LCPD and achieved enough quality scores were included in this study.

\section{Exclusion Criteria}

Papers were excluded if they were case reports or had a patient cohort; were not written in English; lacked documentation; and were nonhuman studies, narrative reviews, studies without clinical outcomes data, systematic reviews that did not pool data or perform a meta-analysis, or technique articles without outcomes. We obtained full manuscripts for those studies that met the inclusion criteria.

\section{Study Selection}

Full texts or abstracts of all studies identified during the advanced search were extracted. After excluding duplicates, we investigated the remaining articles by reviewing the titles, abstracts, and full texts. We also reviewed the findings of the 
articles to prevent reprint bias. Two independent researchers (AM and MNB) selected studies based on the inclusion criteria. Screening was performed after restriction of the search strategy and exclusion of duplicates. Irrelevant studies were removed during the investigation of titles, abstracts, and full texts. The agreement between the selection results of the researchers was assessed based on kappa statistics suggested in the Landis \& Koch guidelines [43]. The agreement was considered as slight (kappa 0-0.20), fair (kappa 0.21-0.40), moderate (kappa 0.41-0.60), substantial (kappa 0.61-0.80), and perfect (kappa $>0.80$ ). We also reviewed the findings of the articles to prevent reprint bias. Then, the quality of the selected articles was assessed using standard scales.

\section{Quality Assessment}

The quality of primary studies was assessed using appropriate standard checklists. We used the Newcastle-Ottawa Quality Assessment Scale and Jadad Scale for quality assessment of primary studies based on the type of study. Additionally, because the aim of this study was not to combine the results of primary studies using meta-analysis, the effect size was not estimated for the outcome. Therefore, evaluation of heterogeneity was not possible using statistical methods, and results were presented in a purely descriptive form based on the planned design for study.

\section{Data Extraction and Analysis}

All required data, such as authors, publication date, study location, sample size, and treatment technique, were extracted from the included studies using a researcher-made form. The review flowchart is presented in Figure 2.

\section{Results}

\section{Overview}

The characteristics of the included studies [1,9,10,32,44-61] are reported in Multimedia Appendix 1.

\section{Etiology and Clinical Manifestations}

One important predisposing factor for this disease is race, with the East Asian race being affected the least and the White race being affected the most. Additionally, latitude has an influence on susceptibility to Perthes disease [62]. Overall, the reported incidence rate is between 0.2 and 19.1 per 100,000 people [55]. Clinical onset tends to be between 4 and 8 years of age [63]. It has been reported that the incidence increases with the increase in latitude. On the other hand, genetics, repetitive trauma, abnormalities of the blood supply, and coagulation disorders are well-described causative factors [64]. The incidence is the lowest in equatorial regions and increases toward Northern Europe. The incidence is the highest in Whites and the lowest in African Americans [65]. It has been reported that a correlation might exist between acetabular retroversion and Perthes disease. However, the correlation of cause and effect is not known [66] It has been demonstrated that circulating leptin is higher than normal in patients with LCPD [7]. Therefore, it can be concluded that obesity can play an important role in the initiation of Perthes disease [55].
The prevalence of Perthes disease in boys is five times more than in girls, and $10 \%$ to $15 \%$ of patients are affected bilaterally; however, bilateral cases are more common in girls [63]. Study findings are conflicting with respect to gender differences in prognosis. Physeal closure in girls occurs earlier, leaving less time for femoral head remodeling [67]. However, no difference between the genders has been detected in final radiographic results. The first presenting complaint is limping, and the second common complaint is pain, which occurs mostly in the anterior hip and medial thigh [55]. The general consensus is that Perthes disease results from the uncoupling of bone metabolism with increased resorption and delayed formation; however, the exact etiology remains unknown. Previous literature states that as patients with LCPD tend to have delayed bone age (on average, 2 years in girls and 1 year in boys), their femoral head ossific nuclei are smaller than those in children of similar age [34]. This makes the cartilaginous component of their epiphysis larger, and the traversing blood vessels are more vulnerable to mechanical compression [68].

\section{Imaging}

Simple radiographs remain the most useful imaging modality, which can be used for the initial diagnosis of LCPD and subsequent follow-up. The size and shape of the femoral head are of importance in this approach $[55,63]$ Characteristic changes usually occur after a radiographically silent period in the first 3 to 6 months of the disease. A relatively thickened cartilage may widen the medial joint space. The involved hip has a smaller ossific nucleus, often with increased radiodensity. An increase in the joint space has been shown to be correlated with enlargement of the femoral head [69]. Prognostic radiographic signs rarely appear until Perthes disease is established, and this usually takes over 6 months after disease onset. Other techniques, such as magnetic resonance imaging and pneumoarthrography, can provide more comprehensive information regarding the stage of the disease [70].

Arthrography as an adjunct to standard radiography aids in the assessment of the range of motion and ability to contain the head in the acetabulum. After general anesthesia and strict sterile preparation, contrast is injected with fluoroscopic guidance to examine the features [71]. Sonography has been reported to detect hip effusion early in the disease when radiographs are undiagnostic [72]. Three-dimensional computed tomography can show early bone collapse, so it can be useful in visualizing complex head deformity, but the benefit of the information gained rarely justifies the radiation dose required [63]. Magnetic resonance imaging details the extent of bony infarction and the anatomy of the cartilaginous head and labrum, which can be useful early in the disease's course to differentiate it from other conditions that cause osteonecrosis $[73,74]$. In bone scanning, there is a strong correlation between the size of the uptake defect on the femoral head and prognosis. The indication is limited to patients who are suspected of being affected by LCPD, which further serves as a prognosticator as well [75]. A previous study showed that there is a significant correlation between hip deformity and labral and cartilage abnormalities of the hip on magnetic resonance imaging, and the main predisposing factors were loss of sphericity of the head and a decline in femoral head-neck offset [76]. 


\section{Surgical Treatment Options}

The treatment of Perthes disease depends on the age and stage of presentation. Simple observation is needed in children aged 2 to 3 years. The optimal treatment technique for LCPD and its prognosis are still not fully understood. In the past 20 years, some authors have tried to standardize the treatment principles for Perthes hip. Extent of femoral head involvement (lateral pillar classification or Catterall classification) and age at diagnosis are the most common classifications used to assess the outcomes following treatment [55]. In a large prospective review by Wiig et al [32], with medium-term follow-up, it was suggested that children aged 6 years or older, with more than $50 \%$ femoral head involvement (Catterall), had a better result if treated with surgery.

\section{Arthrodiastasis}

Arthrodiastasis is a relatively novel treatment method for LCPD, which uses an external fixator. Arthrodiastasis was initially used to describe a technique involving articulated distraction of the hip joint that was developed by surgeons in Verona, Italy, and has been used since 1979 [77]. It has been considered as an alternative treatment for LCPD beyond conventional surgical methods. This method was conceived as a conservative technique of restoring joint function, based on awareness that under certain conditions, regeneration and repair of damaged articular cartilage can occur, at least to some extent [78]. It is considered to be useful because it maintains the mobility of the hip joint and secures space for the femoral head in the joint while minimizing physical pressure and preserving synovial fluid circulation. Kim et al [79] reported that arthrodiastasis using an external fixator can be a relatively promising surgical procedure for the treatment of late-onset LCPD. Additionally, a systematic review by Ibrahim et al [80] investigated relevant literature to assess the efficacy of the use of arthrodiastasis in the management of Perthes disease and showed a significant increase in the postoperative range of motion compared with the preoperative range of motion. Final Stulberg classification was ascertained, and the majority of patients were in stages 2 and 3. Complications were also assessed, with the majority of them being superficial pin tract infections. They concluded that arthrodiastasis is a valid treatment option for Perthes disease; however, more studies need to be performed showing comparative data of arthrodiastasis versus other containment procedures. Arthrodiastasis of the hip joint with soft tissue release is considered as a surgical technique when other treatment options are contraindicated. This method also improves the range of motion, decreases superior and lateral subluxation, and provides better radiographic sphericity of the femoral head. Treatment with distraction may be performed even for stiff hips and hips with deformity [81]. Volpon [17] performed a prospective controlled trial to compare innominate osteotomy and arthrodistraction and concluded that despite similar final radiological outcomes, arthrodistraction was associated with higher morbidity; therefore, hip distraction is not recommended as the primary treatment in the early stages of LCPD.

\section{Salter Osteotomy}

Salter osteotomy, as a method for surgical containment in LCPD, was first introduced in 1962. This technique redirects the acetabulum as well as improves anterolateral femoral head coverage. Salter presented the concept of innominate osteotomy as a containment technique to avoid femoral osteotomy consequences [82]. Salter felt that acetabular rotation would also provide better containment than varus osteotomy of the femur; however, studies have shown little difference in the radiographic or functional results with either of these two techniques. The common indications for salter osteotomy are similar to other forms of containment [39]. Some of these indications include onset age over 6 years, more than $50 \%$ of the femoral head affected, and hip subluxation in the weight-bearing position. This operative method has been reported to produce better long-term outcomes than nonoperative techniques with regard to Stulberg classification [34]. Several studies $[83,84]$ have compared Salter osteotomy and femoral varus osteotomy. Previous studies reported similar outcomes with respect to femoral head sphericity, but have shown increased femoral head coverage by the center-edge angle after Salter osteotomy [85]. Use of this technique can displace the acetabulum $1 \mathrm{~cm}$ medially and distally, thereby reducing the biomechanical stress over the hip joint and improving the generally associated leg length discrepancy [86]. It should be noted that radiographic assessment as well as cautious clinical examination is necessary before surgery. Some of the Salter osteotomy prerequisites include full range of hip motion preoperatively, especially abduction, and reasonable joint congruency [10].

The main benefit of Salter or innominate osteotomy is its effect on femoral head remodeling during remaining growth. This osteotomy alone is commonly indicated for younger children with recent clinical onset and no femoral head deformity or subluxation [39]. However, Salter osteotomy alone may not provide sufficient head coverage in all situations, especially in children older than 9 years. Thus, the combination of Salter and femoral varus osteotomies has been performed recently to manage a larger and deformed femoral head [40,87]. A previous study stated that the combined method of surgery may change the otherwise "poor" hip into a "fair" hip and improve the natural history in children with higher age [87]. The other advantages of the combined method include a reduction in the effect of increased intra-articular pressure from innominate osteotomy and compensation of the shortening from femoral osteotomy [10].

\section{Femoral Varus Osteotomy}

Femoral varus osteotomy has become one of the most popular surgical techniques for Perthes disease, since the first report by Axer in $1965[38,88]$. The aim of this method is to center the femoral head deeply within the acetabulum and allow correction of the flexion or rotational deformity simultaneously [10]. The prerequisites for this technique are good range of motion, hip congruency, and ability to contain the femoral head in abduction. This surgery is suggested in the early stage of fragmentation, when favorable biological and biomechanical effects may be anticipated. Many studies reported that femoral varus osteotomy 
yields good long-term outcomes [37,38]. The reported number of hips treated operatively rose more sharply during the last decade in research from Europe and North America. With regard to the type of surgical treatment, femoral osteotomy was reported more frequently than pelvic osteotomy worldwide; however, pelvic osteotomy is comparably more common in North America, Australia, and South America, whereas femoral osteotomy is more frequently performed in Europe, Asia, and Africa [1].

The main goal of surgical methods is to contain the femoral head within the acetabulum in order to avoid femoral head deformation and subsequent premature hip osteoarthritis. This aim is achievable by the use of femoral varus osteotomy, innominate osteotomy, and other forms of pelvic osteotomies. Operative treatments can roughly be categorized as femoral, pelvic, and combined procedures. A comprehensive review by Braito et al [1] stated that femoral osteotomies were reportedly more frequent than pelvic osteotomies in the screened literature. They concluded that femoral osteotomies were tendentially preferred in Europe. Saran et al [24] showed that children older than 6 years benefit more from varus osteotomy compared with nonoperative treatments. Generally, femoral varus osteotomy allows realignment and identification of the best fit position of the hip, while restoring joint congruity and decreasing femoroacetabular impingement.

\section{Combined Treatments}

Any pelvic osteotomy can be combined with a proximal femoral osteotomy, especially if the femoral head cannot be contained by a pelvic or proximal femoral varus osteotomy alone [39]. The combined Salter and proximal femoral varus osteotomy for LCPD has been performed more recently [89,90]. These combined procedures are usually used for patients with an older age at clinical onset, those with deformed femoral heads, or those in whom osteotomy alone cannot provide adequate containment [39]. Javid and Wedge [87] used combined osteotomies in 20 older patients with LCPD and reported that outcomes improved with the combined osteotomies at skeletal maturity when compared to the natural history of untreated hips. Vukasinovic et al [90] investigated patients treated with combined Salter and proximal femoral shortening osteotomy. They showed a better center-edge angle in these patients. Their results were similar to those reported by other researchers $[83,84]$.

\section{Chiari Osteotomy}

Chiari osteotomy is a popular salvage procedure for children with insufficient femoral head coverage [10]. One of the advantages of this method is the reduction of joint loading by medialization of the hip, which was considered an important factor for improving hip congruency and femoral head remodeling [91]. This technique has been recommended for severe cases of Perthes disease. Medial displacement or Chiari osteotomy is one of the categories of pelvic osteotomies. The most performed methods in Perthes disease are acetabular rotational osteotomies, especially Salter osteotomy. The Chiari medial displacement osteotomy procedure is usually used for salvage of a deformed femoral head [39].

\section{Triple Innominate Osteotomy}

Triple innominate osteotomy is another option for achieving containment in LCPD. Femoral varus osteotomy and Salter osteotomy are the most common techniques for surgical containment; however, the degree of femoral varus osteotomy required to contain the femoral head may further shorten the limb and cause prolonged limp, particularly in older children. On the other hand, use of Salter osteotomy may not provide enough acetabular rotation to cover the femoral head in severe cases, potentially leading to iatrogenic hinge abduction [92]. Because of certain practical limitations with these two procedures, advanced containment methods, such as triple innominate osteotomy, have been developed for more severe cases $[40,93]$. Some studies have reported that older age and extensive femoral head involvement were risk factors for unsatisfactory outcomes. A previous study showed that patients older than 10 years at onset had poor results regardless of surgical treatment [94]. Triple innominate osteotomy is anticipated to show better femoral head containment than can be achieved with Salter osteotomy alone and to avoid the leg length discrepancy associated with femoral varus osteotomy. Finally, this is one of the most efficient methods for femoral head containment in all conditions. However, over coverage can result in pincer impingement. For the prevention of pincer impingement, correction beyond 44 degrees of the enter-edge angle is not recommended [95].

\section{Other Treatment Options}

Lateral shelf acetabuloplasty is considered for severe Perthes disease when redirection osteotomy is thought to be insufficient to produce optimal coverage of the extruded femoral head. An intraoperative dynamic arthrograph is useful for further confirmation. In severe cases, a laterally displaced and enlarged femoral head will preclude normal motion of the hip. Previous reports have shown that shelf acetabuloplasty is a safe and effective method for managing cases with aspherical congruency or incongruency with hinge abduction $[42,96]$. When an arthrograph indicates femoral head deformity with unstable movement and hinge abduction, but stability in adduction and flexion, valgus and extension osteotomy can be an effective method for unloading the deformed epiphyseal segment and alleviating femoroacetabular impingement. The implication of femoral valgus extension osteotomy depends on redirection of the more congruent and round anteromedial part of the femoral head to the neutral position of weight bearing. This sagittal and rotational correction may improve gait and hip motion, decrease pain, and improve femoral head shape [97,98].

Transtrochanteric rotational osteotomy is considered a new technique for patients with onset of LCPD after 9 years of age. It is an effective method to treat late-onset Perthes disease in affected hips. In addition, the amount of head involvement and the lateral pillar influence surgical results [44]. Recent techniques are focused on reshaping the femoral head to match with the acetabulum and reduce impingement, as well as restoring the normal cartilage in the head weight-bearing zone [45]. Total hip arthroplasty is a salvage method for complications and subsequent osteoarthritis. Cementless total hip arthroplasty showed a $90 \%$ survival rate in an 8 -year 
follow-up. However, despite promising outcomes, nerve injury and intraoperative fracture are usual; therefore, care should be taken to avoid excessive limb lengthening [46].

\section{Discussion}

In this study, we reviewed the various surgical treatments for LCPD to provide a guide for clinical applications. Based on the results of the reviewed studies, there are three main factors that influence the treatment outcomes in patients with Perthes disease. These factors include onset age, femoral head involvement severity, and treatment method. For patients aged over 8 years, the prognosis is often poor, but advanced or salvage procedures still provide the benefit of improved femoral head coverage; therefore, they benefit from surgical intervention. For children aged less than 6 years, the prognosis is generally good. For children aged between 6 and 8 years, the prognosis is variable, and it is required to closely observe for the signs of "head at risk," which indicate the need for operation. Once any such signs are observed, dynamic arthrography under anesthesia is valuable before deciding the appropriate treatment approach.

\section{Conflicts of Interest}

None declared.

\section{Multimedia Appendix 1}

The characteristics of the included studies. [DOC File, 55 KB-Multimedia Appendix 1]

\section{References}

1. Braito M, Wolf S, Dammerer D, Giesinger J, Wansch J, Biedermann R. Global differences in the treatment of Legg-Calvé-Perthes disease: a comprehensive review. Arch Orthop Trauma Surg 2021 Jan;141(1):1-16 [FREE Full text] [doi: 10.1007/s00402-020-03392-9] [Medline: $\underline{\text { 32172318] }}$

2. Terjesen T, Wiig O, Svenningsen S. The natural history of Perthes' disease. Acta Orthop 2010 Dec;81(6):708-714 [FREE Full text] [doi: 10.3109/17453674.2010.533935] [Medline: 21067434]

3. Perthes G. The classic: On juvenile arthritis deformans. 1910. Clin Orthop Relat Res 2012 Sep;470(9):2349-2368 [FREE Full text] [doi: 10.1007/s11999-012-2433-1] [Medline: 22744201]

4. Legg AT. An obscure affection of the hip joint. 1910. Clin Orthop Relat Res 2006 Oct;451:11-13 [FREE Full text] [doi: 10.1097/01.BLO.0000238798.05338.13] [Medline: 17038923 ]

5. Calvé J. On a particular form of pseudo-coxalgia associated with a characteristic deformity of the upper end of the femur. 1910. Clin Orthop Relat Res 2006 Oct;451:14-16 [FREE Full text] [doi: 10.1097/01.blo.0000238799.05338.5a] [Medline: 17038924]

6. Atsumi T, Yamano K, Muraki M, Yoshihara S, Kajihara T. The blood supply of the lateral epiphyseal arteries in Perthes' disease. J Bone Joint Surg Br 2000 Apr;82(3):392-398 [FREE Full text] [doi: 10.1302/0301-620x.82b3.10193] [Medline: $\underline{10813176]}$

7. Waldenström H, Goldie I. The First Stages of Coxa Plana. Clinical Orthopaedics and Related Research 1984;191:4-7 [FREE Full text]

8. Weinstein SL. Natural history and treatment outcomes of childhood hip disorders. Clin Orthop Relat Res 1997 Nov(344):227-242. [Medline: 9372774]

9. Herring JA, Kim HT, Browne R. Legg-Calve-Perthes disease. Part I: Classification of radiographs with use of the modified lateral pillar and Stulberg classifications. J Bone Joint Surg Am 2004 Oct;86(10):2103-2120. [Medline: 15466719]

10. Wu K, Wang T, Huang S, Kuo KN. Overview of surgical treatments in Legg-Calvé-Perthes disease. Formosan Journal of Musculoskeletal Disorders 2012 Nov;3(4):111-115. [doi: 10.1016/j.fjmd.2012.09.001]

11. Osman MK, Martin DJ, Sherlock DA. Outcome of late-onset Perthes' disease using four different treatment modalities. J Child Orthop 2009 Jun;3(3):235-242 [FREE Full text] [doi: 10.1007/s11832-009-0175-8] [Medline: 19415362]

12. Engelhardt P. [Late prognosis of Perthes' disease: which factors determine arthritis risk?]. Z Orthop Ihre Grenzgeb 1985;123(2):168-181 [FREE Full text] [doi: 10.1055/s-2008-1045131] [Medline: 4013475]

13. Lecuire F. The long-term outcome of primary osteochondritis of the hip (Legg-Calvé-Perthes' disease). J Bone Joint Surg Br 2002 Jul;84(5):636-640 [FREE Full text] [doi: 10.1302/0301-620x.84b5.12124] [Medline: 12188476]

14. Aquino EML, Barreto SM, Bensenor IM, Carvalho MS, Chor D, Duncan BB, et al. Brazilian Longitudinal Study of Adult Health (ELSA-Brasil): objectives and design. Am J Epidemiol 2012 Feb 15;175(4):315-324 [FREE Full text] [doi: 10.1093/aje/kwr294] [Medline: 22234482]

15. Joseph B. Natural history of early onset and late-onset Legg-Calve-Perthes disease. J Pediatr Orthop 2011 Sep;31(2 Suppl):S152-S155 [FREE Full text] [doi: 10.1097/BPO.0b013e318223b423] [Medline: 21857430]

16. Kim HKW. Pathophysiology and new strategies for the treatment of Legg-Calvé-Perthes disease. J Bone Joint Surg Am 2012 Apr 04;94(7):659-669 [FREE Full text] [doi: 10.2106/JBJS.J.01834] [Medline: 22488623] 
17. Volpon JB. Comparison between innominate osteotomy and arthrodistraction as a primary treatment for Legg-Calvé-Perthes disease: a prospective controlled trial. Int Orthop 2012 Sep;36(9):1899-1905 [FREE Full text] [doi: 10.1007/s00264-012-1598-2] [Medline: 22810494]

18. Arkader A, Sankar WN, Amorim RM. Conservative versus surgical treatment of late-onset Legg-Calve-Perthes disease: a radiographic comparison at skeletal maturity. J Child Orthop 2009 Feb;3(1):21-25 [FREE Full text] [doi: 10.1007/s11832-008-0151-8] [Medline: 19308608]

19. Ishida A, Kuwajima SS, Laredo Filho J, Milani C. Salter innominate osteotomy in the treatment of severe Legg-Calvé-Perthes disease: clinical and radiographic results in 32 patients (37 hips) at skeletal maturity. J Pediatr Orthop 2004;24(3):257-264. [Medline: 15105719$]$

20. Grzegorzewski A, Bowen JR, Guille JT, Glutting J. Treatment of the collapsed femoral head by containment in Legg-Calve-Perthes disease. J Pediatr Orthop 2003;23(1):15-19. [Medline: 12499936]

21. Catterall A. Natural history, classification, and X-ray signs in Legg-Calvé-Perthes' disease. Acta Orthop Belg 1980;46(4):346-351. [Medline: 7223380]

22. Dillman JR, Hernandez RJ. MRI of Legg-Calve-Perthes disease. AJR Am J Roentgenol 2009 Nov;193(5):1394-1407 [FREE Full text] [doi: 10.2214/AJR.09.2444] [Medline: 19843759]

23. de Sanctis N, Rega AN, Rondinella F. Prognostic evaluation of Legg-Calvé-Perthes disease by MRI. Part I: the role of physeal involvement. J Pediatr Orthop 2000;20(4):455-462. [Medline: 10912600]

24. Saran N, Varghese R, Mulpuri K. Do femoral or salter innominate osteotomies improve femoral head sphericity in Legg-Calvé-Perthes disease? A meta-analysis. Clin Orthop Relat Res 2012 Sep;470(9):2383-2393 [FREE Full text] [doi: 10.1007/s11999-012-2326-3] [Medline: 22467420]

25. Norlin R, Hammerby S, Tkaczuk H. The natural history of Perthes' disease. Int Orthop 1991;15(1):13-16 [FREE Full text] [doi: 10.1007/BF00210525] [Medline: 2071274]

26. McAndrew MP, Weinstein SL. A long-term follow-up of Legg-Calvé-Perthes disease. J Bone Joint Surg Am 1984 Jul;66(6):860-869 [FREE Full text] [doi: 10.2106/00004623-198466060-00006] [Medline: 6736087]

27. Harris G. Legg-Calve-Perthes Disease. Medscape. URL: https://emedicine.medscape.com/article/1248267-overview [accessed 2020-12-03]

28. Steinfeld B, Scott J, Vilander G, Marx L, Quirk M, Lindberg J, et al. The Role of Lean Process Improvement in Implementation of Evidence-Based Practices in Behavioral Health Care. J Behav Health Serv Res 2015 Oct;42(4):504-518 [FREE Full text] [doi: 10.1007/s11414-013-9386-3] [Medline: 24464179]

29. Curtis BH, Gunther SF, Gossling HR, Paul SW. Treatment for Legg-Perthes disease with the Newington ambulation-abduction brace. J Bone Joint Surg Am 1974 Sep;56(6):1135-1146 [FREE Full text] [Medline: 4436350]

30. Harrison MH, Turner MH, Smith DN. Perthes' disease. Treatment with the Birmingham splint. J Bone Joint Surg Br 1982;64(1):3-11 [FREE Full text] [doi: 10.1302/0301-620X.64B1.7068716] [Medline: 7068716]

31. Aly TA, Amin OA. Arthrodiatasis for the treatment of Perthes' disease. Orthopedics 2009 Nov 09;32(11):817-818. [doi: 10.3928/01477447-20090922-15] [Medline: 19902893]

32. Wiig O, Terjesen T, Svenningsen S. Prognostic factors and outcome of treatment in Perthes' disease: a prospective study of 368 patients with five-year follow-up. J Bone Joint Surg Br 2008 Oct;90(10):1364-1371 [FREE Full text] [doi: 10.1302/0301-620X.90B10.20649] [Medline: 18827249]

33. Herring JA. Legg-Calvé-Perthes disease at 100: a review of evidence-based treatment. J Pediatr Orthop 2011 Sep;31(2 Suppl):S137-S140 [FREE Full text] [doi: 10.1097/BPO.0b013e318223b52d] [Medline: 21857427]

34. Herring JA, Kim HT, Browne R. Legg-Calve-Perthes disease. Part II: Prospective multicenter study of the effect of treatment on outcome. J Bone Joint Surg Am 2004 Oct;86(10):2121-2134. [Medline: 15466720]

35. Nguyen NT, Klein G, Dogbey G, McCourt JB, Mehlman CT. Operative versus nonoperative treatments for Legg-Calvé-Perthes disease: a meta-analysis. J Pediatr Orthop 2012;32(7):697-705 [FREE Full text] [doi: 10.1097/BPO.0b013e318269c55d] [Medline: 22955534]

36. Kim HKW. Legg-Calvé-Perthes disease. J Am Acad Orthop Surg 2010 Nov;18(11):676-686 [FREE Full text] [doi: 10.5435/00124635-201011000-00005] [Medline: 21041802]

37. Beer Y, Smorgick Y, Oron A, Mirovsky Y, Weigl D, Agar G, et al. Long-term results of proximal femoral osteotomy in Legg-Calvé-Perthes disease. J Pediatr Orthop 2008 Dec;28(8):819-824 [FREE Full text] [doi: 10.1097/BPO.0b013e31818e122b] [Medline: 19034171]

38. Kitakoji T, Hattori T, Iwata H. Femoral varus osteotomy in Legg-Calvé-Perthes disease: points at operation to prevent residual problems. J Pediatr Orthop 1999;19(1):76-81. [Medline: 9890292]

39. Thompson GH. Salter osteotomy in Legg-Calvé-Perthes disease. J Pediatr Orthop 2011 Sep;31(2 Suppl):S192-S197 [FREE Full text] [doi: 10.1097/BPO.0b013e318223b59d] [Medline: 21857438]

40. Wenger DR, Pandya NK. Advanced containment methods for the treatment of Perthes disease: Salter plus varus osteotomy and triple pelvic osteotomy. J Pediatr Orthop 2011 Sep;31(2 Suppl):S198-S205 [FREE Full text] [doi: 10.1097/BPO.0b013e31822602b0] [Medline: 21857439] 
41. Freeman RT, Wainwright AM, Theologis TN, Benson MK. The outcome of patients with hinge abduction in severe Perthes disease treated by shelf acetabuloplasty. J Pediatr Orthop 2008 Sep;28(6):619-625 [FREE Full text] [doi: 10.1097/BPO.0b013e3181804be0] [Medline: 18724197$]$

42. Chang J, Kuo KN, Huang S. Outcomes in advanced Legg-Calvé-Perthes disease treated with the Staheli procedure. J Surg Res 2011 Jun 15;168(2):237-242 [FREE Full text] [doi: 10.1016/j.jss.2009.09.056] [Medline: 20080262]

43. Landis JR, Koch GG. The Measurement of Observer Agreement for Categorical Data. Biometrics 1977 Mar;33(1):159. [doi: 10.2307/2529310]

44. Erkus S, Kalenderer O, Turgut A, Bacaksiz T, Yuksel K. The Effect of Clinical Knowledge and Surgical Experience on Treatment Choice in Legg-Calve-Perthes Disease: Intra-observer and Inter-observer Reliability Study. Indian J Orthop 2020 Jul;54(4):477-485 [FREE Full text] [doi: 10.1007/s43465-020-00047-0] [Medline: 32549963]

45. Ramachandran M, Reed D. Legg-Calvé-Perthes disease of the hip. Surgery (Oxford) 2020 Sep 27;38(9):544-553. [doi: 10.1016/j.mpsur.2020.06.012]

46. Kamegaya M, Morita M, Saisu T, Kakizaki J, Oikawa Y, Segawa Y. Single Versus Combined Procedures for Severely Involved Legg-Calvé-Perthes Disease. J Pediatr Orthop 2018 Jul;38(6):312-319 [FREE Full text] [doi: 10.1097/BPO.0000000000000840] [Medline: 27442215]

47. Mosow N, Vettorazzi E, Breyer S, Ridderbusch K, Stücker R, Rupprecht M. Outcome After Combined Pelvic and Femoral Osteotomies in Patients with Legg-Calvé-Perthes Disease. J Bone Joint Surg Am 2017 Feb 01;99(3):207-213 [FREE Full text] [doi: 10.2106/JBJS.16.00255] [Medline: 28145951]

48. Park KS, Cho KJ, Yang HY, Eshnazarov KE, Yoon TR. Long-term Results of Modified Salter Innominate Osteotomy for Legg-Calvé-Perthes Disease. Clin Orthop Surg 2017 Dec;9(4):397-404 [FREE Full text] [doi: 10.4055/cios.2017.9.4.397] [Medline: 29201291]

49. Stepanovich M, Upasani VV, Bomar JD, Wenger DR. Advanced Containment With Triple Innominate Osteotomy in Legg-Calve-Perthes Disease: A Viable Option Even in Severe Cases. J Pediatr Orthop 2017 Dec;37(8):563-569 [FREE Full text] [doi: 10.1097/BPO.0000000000000714] [Medline: 26683505]

50. Shohat N, Copeliovitch L, Smorgick Y, Atzmon R, Mirovsky Y, Shabshin N, et al. The Long-Term Outcome After Varus Derotational Osteotomy for Legg-Calvé-Perthes Disease: A Mean Follow-up of 42 Years. J Bone Joint Surg Am 2016 Aug 03;98(15):1277-1285 [FREE Full text] [doi: 10.2106/JBJS.15.01349] [Medline: 27489318]

51. Li W, Xu R. Lateral shelf acetabuloplasty for severe Legg-Calvé-Perthes disease in patients older than 8 years: A mean eleven-year follow-up. Medicine (Baltimore) 2016 Nov;95(45):e5272 [FREE Full text] [doi: 10.1097/MD.0000000000005272] [Medline: 27828848]

52. Carsi B, Judd J, Clarke NMP. Shelf acetabuloplasty for containment in the early stages of Legg-Calve-Perthes disease. J Pediatr Orthop 2015 Mar;35(2):151-156 [FREE Full text] [doi: 10.1097/BPO.0000000000000220] [Medline: 24840656]

53. Lim KS, Shim JS. Outcomes of Combined Shelf Acetabuloplasty with Femoral Varus Osteotomy in Severe Legg-Calve-Perthes (LCP) Disease: Advanced Containment Method for Severe LCP Disease. Clin Orthop Surg 2015 Dec;7(4):497-504 [FREE Full text] [doi: 10.4055/cios.2015.7.4.497] [Medline: 26640634]

54. Bulut M, Demirtş A, Uçar BY, Azboy I, Alemdar C, Karakurt L. Salter pelvic osteotomy in the treatment of Legg-Calve-Perthes disease: the medium-term results. Acta Orthop Belg 2014 Mar;80(1):56-62. [Medline: 24873086]

55. Mazloumi S, Ebrahimzadeh M, Kachooei A. Evolution in diagnosis and treatment of Legg-Calve-Perthes disease. Arch Bone Jt Surg 2014 Jun;2(2):86-92 [FREE Full text] [Medline: 25207324]

56. Yoo WJ, Choi IH, Moon HJ, Chang S, Cho T, Choi YH, et al. Valgus femoral osteotomy for noncontainable Perthes hips: prognostic factors of remodeling. J Pediatr Orthop 2013 Sep;33(6):650-655 [FREE Full text] [doi: 10.1097/BPO.0b013e31829569c8] [Medline: 23812133]

57. Terjesen T, Wiig O, Svenningsen S. Varus femoral osteotomy improves sphericity of the femoral head in older children with severe form of Legg-Calvé-Perthes disease. Clin Orthop Relat Res 2012 Sep;470(9):2394-2401 [FREE Full text] [doi: 10.1007/s11999-011-2181-7] [Medline: 22101403]

58. Hosny GA, El-Deeb K, Fadel M, Laklouk M. Arthrodiastasis of the hip. J Pediatr Orthop 2011 Sep;31(2 Suppl):S229-S234 [FREE Full text] [doi: 10.1097/BPO.0b013e318223b45a] [Medline: 21857444]

59. Glard Y, Katchburian MV, Jacquemier M, Guillaume J, Bollini G. Genu valgum in Legg-Calvé-Perthes disease treated with femoral varus osteotomy. Clin Orthop Relat Res 2009 Jun;467(6):1587-1590 [FREE Full text] [doi: 10.1007/s11999-009-0727-8] [Medline: 19214643 ]

60. Castañeda P, Haynes R, Mijares J, Quevedo H, Cassis N. Varus-producing osteotomy for patients with lateral pillar type B and C Legg-Calvé-Perthes disease followed to skeletal maturity. J Child Orthop 2008 Oct;2(5):373-379 [FREE Full text] [doi: 10.1007/s11832-008-0125-x] [Medline: 19308570]

61. Rowe S, Moon E, Song E, Yoon T, Kim M, Cho S. Residual shortening after Legg-Calve-Perthes disease, focusing on the response of the ipsilateral tibia. J Pediatr Orthop 2005;25(3):296-299 [FREE Full text] [doi:

10.1097/01.bpo.0000151060.85227.67] [Medline: 15832141$]$

62. Perry DC, Machin DMG, Pope D, Bruce CE, Dangerfield P, Platt MJ, et al. Racial and geographic factors in the incidence of Legg-Calvé-Perthes' disease: a systematic review. Am J Epidemiol 2012 Feb 01;175(3):159-166 [FREE Full text] [doi: 10.1093/aje/kwr293] [Medline: 22223709] 
63. Chaudhry S, Phillips D, Feldman D. Legg-Calvé-Perthes disease: an overview with recent literature. Bull Hosp Jt Dis (2013) 2014;72(1):18-27 [FREE Full text] [Medline: 25150324]

64. Al-Omran A, Sadat-Ali M. Legg-Calve-Perthes disease in two generations of male family members: a case report. J Orthop Surg (Hong Kong) 2013 Aug;21(2):258-261 [FREE Full text] [doi: 10.1177/230949901302100230] [Medline: 24014797]

65. Perry D. The Epidemiology and Etiology of Perthes' Disease. In: Koo KH, Mont M, Jones L, editors. Osteonecrosis. Berlin, Heidelberg: Springer; 2014:419-425.

66. Kawahara S, Nakashima Y, Oketani H, Wada A, Fujii M, Yamamoto T, et al. High prevalence of acetabular retroversion in both affected and unaffected hips after Legg-Calvé-Perthes disease. J Orthop Sci 2012 May;17(3):226-232 [FREE Full text] [doi: 10.1007/s00776-012-0213-0] [Medline: 22431008]

67. Guille J, Lipton G, Szöke G, Bowen J, Harcke H, Glutting J. Legg-Calvé-Perthes disease in girls. A comparison of the results with those seen in boys. J Bone Joint Surg Am 1998 Sep;80(9):1256-1263 [FREE Full text] [doi:

10.2106/00004623-199809000-00002] [Medline: 9759808]

68. Little DG, Kim HK. Future biologic treatments for Perthes disease. Orthop Clin North Am 2011 Jul;42(3):423-7, viii [FREE Full text] [doi: 10.1016/j.ocl.2011.03.001] [Medline: 21742154]

69. Vijayan S, Mehta O, Jacob G, Siddesh ND, Shah H, Joseph B. The fate of the joint space in Legg-Calvé-Perthes' disease. Skeletal Radiol 2013 Mar 20;42(3):341-345 [FREE Full text] [doi: 10.1007/s00256-012-1474-6] [Medline: 22714126]

70. Milani C, Dobashi ET. Arthrogram in Legg-Calvé-Perthes disease. J Pediatr Orthop 2011 Sep;31(2 Suppl):S156-S162. [doi: 10.1097/BPO.0b013e318223b441] [Medline: 21857431]

71. Nakamura J, Kamegaya M, Saisu T, Kenmoku T, Takahashi K, Harada Y. Hip arthrography under general anesthesia to refine the definition of hinge abduction in Legg-Calvé-Perthes disease. J Pediatr Orthop 2008 Sep;28(6):614-618. [doi: 10.1097/BPO.0b013e3181842013] [Medline: 18724196]

72. Futami T, Kasahara Y, Suzuki S, Ushikubo S, Tsuchiya T. Ultrasonography in transient synovitis and early Perthes' disease. The Journal of Bone and Joint Surgery. British volume 1991 Jul;73-B(4):635-639 [FREE Full text] [doi: 10.1302/0301-620x.73b4.2071649]

73. Kim H, Oh M, Lee J. MR imaging as a supplement to traditional decision-making in the treatment of LCP disease. J Pediatr Orthop 2011;31(3):246-253. [doi: 10.1097/BPO.0b013e31820fc63c] [Medline: 21415682]

74. Lobert PF, Dillman JR, Strouse PJ, Hernandez RJ. Unexpected MRI findings in clinically suspected Legg-Calvé-Perthes disease. Pediatr Radiol 2011 Mar 24;41(3):369-373 [FREE Full text] [doi: 10.1007/s00247-010-1841-1] [Medline: 20865410]

75. Fisher RL, Roderique JW, Brown DC, Danigelis JA, Ozonoff MB, Sziklas JJ. The Relationship of Isotopic Bone Imaging Findings to Prognosis in Legg-Perthes Disease. Clinical Orthopaedics and Related Research 1980:23-29. [doi: 10.1097/00003086-198007000-00007]

76. Maranho D, Nogueira-Barbosa M, Zamarioli A, Volpon J. MRI abnormalities of the acetabular labrum and articular cartilage are common in healed Legg-Calvé-Perthes disease with residual deformities of the hip. J Bone Joint Surg Am 2013 Feb 06;95(3):256-265. [doi: 10.2106/JBJS.K.01039] [Medline: 23389789]

77. Kucukkaya M, Kabukcuoglu Y, Ozturk I, Kuzgun U. Avascular Necrosis of the Femoral Head in Childhood: The Results of Treatment with Articulated Distraction Method. Journal of Pediatric Orthopaedics 2000;20(6):722-728 [REEE Full text] [doi: 10.1097/01241398-200011000-00005]

78. Judet R, Judet T. [The use of a hinge distraction apparatus after arthrolysis and arthroplasty (author's transl)]. Rev Chir Orthop Reparatrice Appar Mot 1978;64(5):353-365. [Medline: 152944]

79. Kim SS, Lee CW, Kim HJ, Kim HH, Wang L. Treatment of Late-Onset Legg-Calve-Perthes Disease by Arthrodiastasis. Clin Orthop Surg 2016 Dec;8(4):452-457 [FREE Full text] [doi: 10.4055/cios.2016.8.4.452] [Medline: 27904729]

80. Ibrahim YH, Kersh MAAL, Fahmy H. Arthrodiastasis in the management of Perthes disease: a systematic review. J Pediatr Orthop B 2020 Nov;29(6):550-555. [doi: 10.1097/BPB.0000000000000690] [Medline: 31856037]

81. Laklouk M, Hosny G. Hinged distraction of the hip joint in the treatment of Perthes disease: evaluation at skeletal maturity. J Pediatr Orthop B 2012 Sep;21(5):386-393. [doi: 10.1097/BPB.0b013e328354b0ab] [Medline: 22713742]

82. Salter R. Legg-Perthes' disease. Treatment by innominate osteotomy. AAOS Instruc Course Lect 1973;22:309-316.

83. Moberg A, Hansson G, Kaniklides C. Results After Femoral and Innominate Osteotomy in Legg-Calv??-Perthes Disease. Clinical Orthopaedics and Related Research 1997;334:257-264. [doi: 10.1097/00003086-199701000-00033]

84. Kitakoji T, Hattori T, Kitoh H, Katoh M, Ishiguro N. Which is a better method for Perthes' disease: femoral varus or Salter osteotomy? Clin Orthop Relat Res 2005 Jan(430):163-170 [FRE Full text] [doi: 10.1097/01.blo.0000137549.60694.63] [Medline: 15662319]

85. Rab GT. Biomechanical Aspects of Salter Osteotomy. Clinical Orthopaedics and Related Research 1978;132:82-87 [FREE Full text] [doi: 10.1097/00003086-197805000-00017]

86. Grzegorzewski A, Synder M, Kozłowski P, Szymczak W, Bowen RJ. Leg length discrepancy in Legg-Calve-Perthes disease. J Pediatr Orthop 2005;25(2):206-209 [FREE Full text] [doi: 10.1097/01.bpo.0000148497.05181.51] [Medline: 15718903]

87. Javid M, Wedge JH. Radiographic results of combined Salter innominate and femoral osteotomy in Legg-Calvé-Perthes disease in older children. J Child Orthop 2009 Jun;3(3):229-234 [FREE Full text] [doi: 10.1007/s11832-009-0171-z] [Medline: 19387716] 
88. Axer A. Subtrochanteric osteotomy and spline fixation for certain disabilities of the hip joint; a preliminary report. J Bone Joint Surg Am 1951 Apr;33-A(2):351-361. [Medline: $\underline{\text { 14824183] }}$

89. Olney BW, Asher MA. Combined innominate and femoral osteotomy for the treatment of severe Legg-Calvé-Perthes disease. J Pediatr Orthop 1985;5(6):645-651 [FREE Full text] [doi: 10.1097/01241398-198511000-00003] [Medline: 4066935]

90. Vukasinovic Z, Slavkovic S, Milickovic S, Siqeca A. Combined salter innominate osteotomy with femoral shortening versus other methods of treatment for Legg-Calvé-Perthes disease. J Pediatr Orthop B 2000 Jan;9(1):28-33 [FREE Full text] [doi: 10.1097/01202412-200001000-00006] [Medline: 10647106]

91. Reddy RR, Morin C. Chiari osteotomy in Legg-Calve-Perthes disease. J Pediatr Orthop B 2005 Jan;14(1):1-9 [FREE Full text] [doi: 10.1097/01202412-200501000-00001] [Medline: 15577300]

92. Rab GT. Theoretical study of subluxation in early Legg-Calvé-Perthes disease. J Pediatr Orthop 2005;25(6):728-733 [REEE Full text] [doi: 10.1097/01.bpo.0000184649.88733.fc] [Medline: 16294126]

93. Wenger DR, Pring ME, Hosalkar HS, Caltoum CB, Lalonde FD, Bastrom TP. Advanced containment methods for Legg-Calvé-Perthes disease: results of triple pelvic osteotomy. J Pediatr Orthop 2010 Dec;30(8):749-757. [doi: 10.1097/BPO.0b013e3181f5a0de] [Medline: 21102197]

94. Sponseller PD, Desai SS, Millis MB. Comparison of femoral and innominate osteotomies for the treatment of Legg-Calvé-Perthes disease. The Journal of Bone \& Joint Surgery 1988;70(8):1131-1139 [FREE Full text] [doi: 10.2106/00004623-198870080-00003]

95. Hosalkar H, Munhoz da Cunha AL, Baldwin K, Ziebarth K, Wenger D. Triple innominate osteotomy for Legg-Calvé-Perthes disease in children: does the lateral coverage change with time? Clin Orthop Relat Res 2012 Sep;470(9):2402-2410 [FREE Full text] [doi: 10.1007/s11999-011-2189-z] [Medline: 22125244]

96. Ghanem I, Haddad E, Haidar R, Haddad-Zebouni S, Aoun N, Dagher F, et al. Lateral shelf acetabuloplasty in the treatment of Legg-Calvé-Perthes disease: improving mid-term outcome in severely deformed hips. J Child Orthop 2010 Feb;4(1):13-20 [FREE Full text] [doi: 10.1007/s11832-009-0216-3] [Medline: 19911218]

97. Yoo WJ, Choi IH, Chung CY, Cho T, Kim HY. Valgus femoral osteotomy for hinge abduction in Perthes' disease. Decision-making and outcomes. J Bone Joint Surg Br 2004 Jul;86(5):726-730 [FREE Full text] [doi: 10.1302/0301-620x.86b5.13897] [Medline: 15274271]

98. Choi IH, Yoo WJ, Cho T, Moon HJ. The role of valgus osteotomy in LCPD. J Pediatr Orthop 2011 Sep;31(2 Suppl):S217-S222. [doi: 10.1097/BPO.0b013e318223b404] [Medline: 21857442]

\section{Abbreviations}

LCPD: Legg-Calvé-Perthes disease

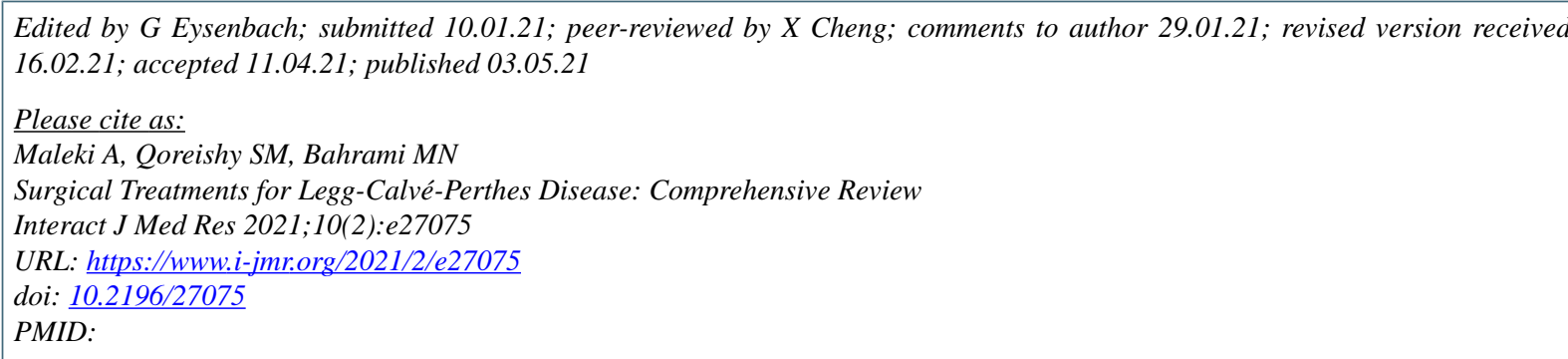

(C)Arash Maleki, Seyyed Mohammad Qoreishy, Mohammad Nabi Bahrami. Originally published in the Interactive Journal of Medical Research (https://www.i-jmr.org/), 03.05.2021. This is an open-access article distributed under the terms of the Creative Commons Attribution License (https://creativecommons.org/licenses/by/4.0/), which permits unrestricted use, distribution, and reproduction in any medium, provided the original work, first published in the Interactive Journal of Medical Research, is properly cited. The complete bibliographic information, a link to the original publication on https://www.i-jmr.org/, as well as this copyright and license information must be included. 